\title{
Boombestuurskundetijdschriften
}

\section{Wat wendbare organisaties doen (en laten)}

Drs. Mark Nijssen, Dr. Brenda Vermeeren, Drs. Lucien Vermeer en Ir. Jurgen Visser

Aanbevolen citeerwijze bij dit artikel

Drs. Mark Nijssen, Dr. Brenda Vermeeren, Drs. Lucien Vermeer e.a. , 'Wat

wendbare organisaties doen (en laten)', Bestuurskunde 2018-4, p. 79-93

Overheidsorganisaties hebben te maken met elkaar in snel tempo opvolgende veranderingen in hun omgeving. Tegen deze achtergrond zien en horen we steeds vaker een roep om wendbare overheidsorganisaties. Maar wat is wendbaarheid dan precies? En hoe kun je dat dan bereiken? In dit onderzoek hebben we het concept van wendbaar vermogen ontwikkeld en gevalideerd en identificeren we empirisch het afzonderlijke effect van verschillende managementpraktijken die bijdragen aan wendbaarheid. Dit onderzoek laat zien dat het niet voor alle organisatieonderdelen bij de overheid noodzakelijk is om een wendbare organisatie te zijn, bezien vanuit het perspectief van de ervaren dynamiek. Tegelijkertijd is er een substantiële groep die gezien de dynamiek die zij tegenkomt wendbaarder zou mogen zijn. Het onderzoek laat zien dat wendbare organisaties meer inzetten op het bevorderen van een eenduidige interpretatie van de situatie door medewerkers, meer autonomie voor besluitvorming bieden en het werken met nieuwe ideeën en inzichten bevorderen.

\section{Inleiding: roep om wendbaarheid van overheidsorganisaties}

Overheidsorganisaties hebben te maken met elkaar in snel tempo opvolgende veranderingen in hun omgeving, zoals de opkomst van nieuwe technologieën, maatschappelijke ontwikkelingen en veranderende politieke prioriteiten. Tegen deze achtergrond zien en horen we steeds vaker een roep om wendbare overheidsorganisaties. De gedachte is dat wendbare organisaties snel en adequaat kunnen inspelen op veranderingen in de omgeving. Zo stelden de secretarissen-generaal in een brief aan toenmalig informateur Schippers in maart 2017, dat het belangriik is 'om te investeren in een kwalitatief nog betere overheid, die 
responsieve of adaptieve organisatie. In het essay 'Adaptief bestuur: organiseren voor een voorspelbaar verrassende toekomst' legt Van der Steen (2018) het verband tussen adaptief bestuur en de inrichting van de organisatie. In de kern komen al deze termen voort uit de behoefte om een organisatie neer te zetten die in staat is om te gaan met - of zelfs kansen te pakken in - een dynamische, lastig te voorspellen omgeving. In dit artikel gebruiken we de term wendbaarheid. Het begrip wendbaarheid wordt breed gebruikt. Niet alleen in de praktijk van organisatie-inrichting, maar ook in de wetenschappelijke literatuur. Hier zien we voorbeelden die uiteenlopen van wendbare strategie (Goldman, Nagel, Preiss, 1995) tot wendbare supply chains (Christopher, 2000) en van wendbare informatiesystemen (Huang, 1999) tot wendbare medewerkers (Van Oyen, Gel, \& Hopp, 2001). In dit artikel richten we ons op het wendbaar organiseren van mensen (Dyer \& Shafer, 2003). Met dit artikel leveren we twee bijdragen. Om te beginnen hebben we een survey ontwikkeld om aan de hand van gestandaardiseerde vragen het concept van wendbaarheid te ontwikkelen en te valideren. Vervolgens bouwen wij voort op eerder kwalitatief onderzoek van Nijssen en Paauwe (2012a; 2012b). Zij identificeerden op basis van casestudieonderzoek managementpraktijken die lijken bij te dragen aan de wendbaarheid van de organisatie. Aan de hand van kwantitatief onderzoek stellen we vast welke managementpraktijken daadwerkelijk een voorspeller zijn (en in welke mate) voor de wendbaarheid van organisaties. De praktische bijdrage is dat we hierdoor beleidsmakers en bestuurders handvatten bieden om nog effectiever en gerichter te kunnen werken aan de wendbaarheid van hun organisatie.

\section{Wat is een wendbare organisatie?}

Dynamiek in de omgeving van organisaties heeft in de strategischmanagementliteratuur geleid tot een focus op het concept van dynamische vermogens. Helfat et al. (2007) maken een onderscheid tussen operationele en dynamische vermogens. De operationele vermogens stellen organisaties in staat om hun voortbestaan in het nu veilig te stellen, terwijl de dynamische vermogens zijn gericht op het voortbestaan in de toekomst. Voorbeelden van operationele vermogens zijn het vermogen om de snelste auto te maken, de beste dienstverlening neer te zetten of op de meest effectieve manier publieke taken uit te voeren. Een dynamisch vermogen is erop gericht om van operationeel vermogen te kunnen veranderen wanneer veranderingen in de omgeving hierom vragen. Bijvoorbeeld het vermogen van het Centraal Orgaan opvang Asielzoekers (COA) om bij een plotselinge groei van de vluchtelingenstroom in zeer korte tijd de beschikbare inzet sterk te laten groeien.

Om deze verandering te realiseren moet de organisatie 'doelgericht de samenstelling en inzet van haar middelen creëren, uitbreiden en aanpassen' (Helfat et al., 2007, p. 4). Onderzoek heeft verschillende dynamische vermogens opgeleverd, vaak gericht op innovatie en $R \& D$, overnames of strategische besluitvorming. In dit artikel richten we ons op een van deze dynamische vermogens, namelijk wendbaar organiseren. 
realiseren van veranderingen in de samenstelling en inzet van middelen. Wanneer het gaat over wendbare organisaties, dan ligt de focus al gauw op een specifieke categorie 'middelen': medewerkers. Deze categorie middelen voldoet veelal aan de eisen van moeilijk te imiteren, moeilijk te vervangen, waardevol en schaars. We zien deze aandacht voor mensen zowel in de praktijk van organisaties (zie het Strategisch Personeelsbeleid Rijk) als in de relevante literatuur (zie bijvoorbeeld Dyer \& Shafer, 1999; 2003; Van Oyen, Gel, \& Hopp, 2001). Derhalve voegen we de inzichten uit het HRM-veld toe aan dynamische vermogens. Ulrich en Lake (1990) bieden een HRM-perspectief op organisatievermogens - en daarmee ook op dynamische vermogens - en definiëren deze als het vermogen om 'mensen te managen voor concurrentievoordeel, met een focus op interne structuren en processen'. Concurrentievoordeel vatten we in deze context op als het veiligstellen van het voortbestaan van de organisatie in een dynamische, onvoorspelbare omgeving.

\section{Concepten nader uitgewerkt}

Om antwoord te kunnen geven op de vraag welke managementpraktijken wendbare organisaties toepassen, is het van belang om wendbare organisaties te kunnen identificeren. Het wendbaar zijn als organisatie is van belang in een dynamische omgeving. Hieronder zetten we de concepten dynamiek in de omgeving en wendbaarheid van de organisatie uiteen.

\section{Dynamiek in de omgeving}

Welke vorm dynamiek ook aanneemt (radicaal of mild, abstract of gedetailleerd), er zijn altijd twee kenmerkende eigenschappen die de dynamiek relevant maken voor organisaties: de mate van voorspelbaarheid en de impact op de organisatie (Miles, Snow, \& Pfeffer, 1974; Dess \& Beard, 1984). Als verandering makkelijk te voorspellen is, dan is het relatief eenvoudig om hier klaar voor te zijn. Wanneer veranderingen geen impact hebben op de organisatie, dan is het niet nodig om er klaar voor te zijn. Een organisatie die vooral geconfronteerd wordt met weinig of voorspelbare veranderingen, of met veranderingen die nauwelijks een impact hebben op de organisatie, hebben daarmee dus ook minder baat bij wendbaarheid.

\section{Wendbaarheid van de organisatie}

Helfat et al. (2007) komen tot de conclusie dat een dynamisch vermogen - zoals wendbaar organiseren - vooral erop gericht is om het anders te doen, niet noodzakelijkerwijs om het beter te doen. Dit moet leiden tot 'evolutionary fit', ofwel het vermogen om 'te overleven en misschien te groeien, en te bloeien in de markt' (Helfat et al., 2007, p. 7). Om het vermogen van wendbare organisaties te kunnen operationaliseren, is het zaak om de processen van dynamische vermogens te kennen die leiden tot evolutionary fitness. Dit zijn het identificeren van kansen en bedreigingen, het formuleren van en besluiten over de best passende 
van veranderingen is voor de wendbaarheid bijvoorbeeld nutteloos als men niet in staat is om snel besluiten te nemen. Of als besluiten snel worden genomen, maar traag worden geïmplementeerd, dan is de wendbaarheid eveneens beperkt.

\section{Drie soorten managementpraktijken voor wendbaarheid}

Tot slot is het zaak om te kijken naar de interne structuren en processen die bijdragen aan het gestelde vermogen (Ulrich \& Lake, 1990). Hierbij maken we gebruik van casestudieonderzoek van Nijssen en Paauwe (2012a; 2012b). Zij concluderen dat er drie soorten managementpraktijken zijn die bij kunnen dragen aan de wendbaarheid van een organisatie:

1. Schaalbaarheid van het personeelsbestand: dit betreft de mogelijkheid om het personeelsbestand - in zowel kwantitatieve als kwalitatieve zin - aan te passen aan veranderende omstandigheden (Dyer \& Ericksen, 2006) om telkens opnieuw aan te kunnen sluiten bij de dynamische eisen die de omgeving stelt.

2. Snel lerende organisatie: wanneer het personeelsbestand voortdurend in beweging is, bestaat het risico van kennisverlies en verminderde samenhang. Daarom is het vermogen van 'snel leren' noodzakelijk. Dit zijn activiteiten die betrekking hebben op het constant en snel verwerven en toepassen van kennis in de organisatie, die noodzakelijk is om in te spelen op veranderende omstandigheden.

3. Aanpasbare organisatiestructuur: dit betreft de wijze waarop een organisatie in staat is haar organisatiestructuur aan te passen aan de nieuwe omstandigheden, of wanneer zij haar organisatiestructuur zo heeft ingericht dat aanpassing van de structuur niet noodzakelijk is (Volberda, 1998; Dyer \& Shafer, 1999).

Bovenstaande concepten hebben we samengevat in onderstaand model (figuur 1). Hierin veronderstellen we dat een dynamische omgeving vraagt om een wendbare organisatie. Hierbij geldt dat naarmate de dynamiek toeneemt, ook de behoefte aan wendbaarheid van de organisatie toeneemt. Om die wendbaarheid te realiseren, veronderstellen wij dat het noodzakelijk is dat de organisatie managementpraktijken toepast gericht op de schaalbaarheid van het personeelsbestand, de snel lerende organisatie en de aanpasbare organisatiestructuur.

\section{Overzicht van de centrale concepten}

\begin{tabular}{|c|c|c|c|c|}
\hline \multirow[t]{2}{*}{$\begin{array}{l}\text { Dynamische omgeving: } \\
\text { - Frequente verandering } \\
\text { - Die onvoorspelbaar is } \\
\text { - En een impact heeft op } \\
\text { de organisatie }\end{array}$} & vraagt om: & \multirow{2}{*}{$\begin{array}{l}\text { Wendbaar vermogen: } \\
\text { 1. Het tijdig signaleren van } \\
\text { veranderingen } \\
\text { 2. Het snel kunnen bedenken van } \\
\text { passende maatregelen } \\
\text { 3. Het snel besluiten kunnen nemen } \\
\text { over de te nemen maatregelen }\end{array}$} & vraagt om: & \multirow{2}{*}{$\begin{array}{l}\text { Managementpraktijken voor } \\
\text { wendbare organisaties: } \\
\text { - Schaalbaar } \\
\text { personeelsbestand } \\
\text { - Snel lerende organisatie } \\
\text { - Aanpasbare } \\
\text { organisatiestructuur }\end{array}$} \\
\hline & & & & \\
\hline
\end{tabular}




\section{Methodologie}

\section{Steekproef en respons}

Voor het onderzoek hebben we gebruik gemaakt van twee verschillende panels. Allereerst het Flitspanel, een initiatief van het ministerie van Binnenlandse Zaken en Koninkrijksrelaties. Het beheer van het panel ligt bij ICTU-InternetSpiegel en de uitvoering van het onderzoek wordt verzorgd door marktpartij GfK. Voor dit onderzoek zijn alle 20.220 panelleden (onder wie 3578 leidinggevenden) benaderd. Voor deze studie gebruiken we alleen de data van ambtenaren met een leidinggevende functie die werkzaam zijn in de publieke sector $(=799)$. Dit betreft een respons van 22 procent. Ter referentie van de onderzoeksresultaten hebben we eveneens het marktpanel van GfK gebruikt. In het marktpanel zijn 1800 leidinggevenden benaderd. 506 leidinggevenden uit de private sector hebben de vragenlijst ingevuld. Dit betreft een respons van 28 procent. Het onderzoek heeft plaatsgevonden van 6 tot en met 25 juli 2017.

We hebben leidinggevenden in het onderzoek gevraagd hun perceptie van dynamiek, hun perceptie van de mate van wendbaarheid en de aanwezigheid van managementpraktijken van hun organisatieonderdeel aan te geven. Hierin zit een aantal methodologische keuzes. Om te beginnen richten we ons op de lijnmanagers in de organisatie. Zo vragen we leidinggevenden onder andere om de aanwezigheid van specifieke managementpraktijken aan te geven. Hiermee houden we rekening met wat Nishii en Wright (2008) variabiliteit binnen organisaties noemen: het verschijnsel dat binnen een organisatie niet in elk onderdeel van de organisatie dezelfde managementpraktijken worden toegepast, of niet op dezelfde manier worden toegepast. Managementpraktijken worden gepland op organisatieniveau, maar worden in de organisatie uitgevoerd door de leidinggevenden, ieder voor hun eigen onderdeel.

Verder vragen we leidinggevenden in dit onderzoek naar de perceptie van dynamiek en de mate van wendbaarheid. Beide zijn benaderingen van de ideale situatie waarin we de feitelijke dynamiek en feitelijke mate van wendbaarheid zouden vaststellen. De mate van dynamiek verschilt echter per organisatie. Afhankelijk van de doelstelling van de organisatie verandert ook de relevante omgeving van de organisatie. Bovendien kan men betogen dat dynamiek perceptie is, en uiteindelijk bepaalt deze perceptie of men wel of niet de managementpraktijken gericht op wendbaarheid inzet. Verder laat eerder onderzoek zien dat er een sterke correlatie is tussen objectieve en subjectieve metingen van het functioneren van organisaties (Wall et al., 2004). Met andere woorden, wanneer leidinggevenden veel dynamiek of een hoge wendbaarheid ervaren, dan is het aannemelijk dat er ook feitelijk sprake is van veel dynamiek of een hoge wendbaarheid.

Tot slot vragen we de respondenten naar het organisatieonderdeel. Er geldt namelijk ook een verschil in dynamiek per organisatieonderdeel (en daarmee ook in de behoefte aan wendbaarheid). Zeker in de publieke sector vervult één organisatie vaak veel verschillende rollen op verschillende terreinen. De mate van dynamiek waarmee de organisatie 
bijvoorbeeld voor een gemeente de dynamiek in het sociale domein anders dan de dynamiek in het fysieke domein.

\section{Operationalisering}

Wendbaarheid: aan de respondenten zijn vier stellingen voorgelegd over wendbaarheid, gebaseerd op de definitie van Helfat et al. (2007), namelijk: in ons organisatieonderdeel (1) signaleren we tijdig relevante ontwikkelingen buiten onze organisatie, (2) bedenken we snel passende maatregelen zodra veranderingen zich voordoen, (3) nemen we snel besluiten over te nemen maatregelen, en (4) implementeren we snel de genomen besluiten. Respondenten konden antwoorden op een vijfpuntsschaal, lopend van 1 (helemaal mee oneens) tot 5 (helemaal mee eens). Hieruit kunnen we een homogene samengestelde variabele voor wendbaarheid vaststellen (Cronbach's alpha $=, 79$ ).

Dynamiek: de ervaren dynamiek hebben we in kaart gebracht door middel van twee vragen: (1) in welke mate ervaren leidinggevenden in de afgelopen vijf jaar veranderingen in de omgeving van hun organisatie; en (2) in welke mate waren deze veranderingen onvoorspelbaar? De eerste vraag heeft betrekking op de frequentie van veranderingen. De tweede vraag heeft betrekking op de eerder omschreven mate van onvoorspelbaarheid (Miles, Snow, \& Pfeffer, 1974; Dess \& Beard, 1984). Ten slotte hebben we - in lijn met de eerdere uitwerking van de concepten - in de toelichting aangegeven dat het moet gaan over veranderingen die een impact hebben op de organisatie. Deze impact hebben we gedefinieerd als veranderingen die invloed hadden op de manier waarop uw organisatieonderdeel de financiële/personele/technische middelen inzet'. Daarbij hebben we vijf terreinen voorgelegd waarop zich veranderingen kunnen voordoen: veranderingen bij klanten/burgers/cliënten, veranderingen in wetgeving, technologische veranderingen, veranderingen door politieke keuzes en economische veranderingen. Respondenten konden antwoorden op een vijfpuntsschaal, lopend van 1 (nooit) tot 5 (heel vaak). We spreken van hoge dynamiek als een respondent op minimaal één van deze gebieden (heel) vaak veranderingen ervaart en deze veranderingen (heel) vaak onvoorspelbaar zijn. Met andere woorden: een combinatie van een hoge frequentie met een hoge onvoorspelbaarheid.

Managementpraktijken: we hebben in het onderzoek 53 managementpraktijken op basis van het casestudieonderzoek van Nijssen en Paauwe (2012b), verdeeld over de drie eerdergenoemde hoofdsoorten, voorgelegd aan leidinggevenden en aan hen gevraagd in hoeverre deze aanwezig waren in het organisatieonderdeel. Respondenten konden antwoorden op een vijfpuntsschaal, lopend van 1 (helemaal mee oneens) tot 5 (helemaal mee eens). In deze studie kijken we naar het afzonderlijk effect van elk van deze 53 managementpraktijken, aangezien sommige managementpraktijken bij meerdere van de eerdergenoemde hoofdsoorten passen (zie tabel 4 voor een overzicht van de managementpraktijken).

Controlevariabelen: in dit onderzoek hebben we verschillende controlevariabelen meegenomen. Om te beginnen hebben we 
lopend van 16 tot 67 jaar) en span of control (categorale variabele lopend van $1=1-5$ medewerkers tot $5=$ meer dan 50 medewerkers). Daarnaast hebben we gecontroleerd voor kenmerken van de organisatie, namelijk sector (dummyvariabele $\mathrm{o}=$ privaat, $1=$ publiek), omvang van de organisatie en omvang van het organisatieonderdeel (beide categorale variabelen lopend van $\mathbf{1}=\mathbf{0 - 2 5}$ medewerkers tot $9=$ meer dan 5000 medewerkers).

\section{Resultaten}

We spreken van hoge wendbaarheid als een respondent op alle vier de stellingen over wendbaarheid (helemaal) mee eens heeft geantwoord. 19,7\% van de leidinggevenden in de publieke sector ziet de organisatie als hoog wendbaar tegenover $34 \%$ in de private sector (zie tabel 1). De verschillen tussen deze sectoren zijn statistisch significant.

Tabel 1 Ervaren wendbaarheid per sector

\begin{tabular}{|l|l|l|}
\hline & Lage wendbaarheid & Hoge wendbaarheid \\
\hline Publieke sector & $80,3 \%$ & $19,7 \%$ \\
\hline Private sector & $66,0 \%$ & $34,0 \%$ \\
\hline
\end{tabular}

Daar staat tegenover dat lang niet iedereen dynamiek ervaart in de omgeving: $34,2 \%$ van de leidinggevenden in de publieke sector zegt een hoge dynamiek te ervaren. In de private sector ligt dit percentage vrijwel op hetzelfde niveau (30,9\%) (zie tabel 2). De verschillen tussen beide sectoren zijn niet statistisch significant.

Tabel 2 Ervaren dynamiek per sector

\begin{tabular}{|l|l|l|}
\hline & Lage dynamiek & Hoge dynamiek \\
\hline Publieke sector & $65,8 \%$ & $34,2 \%$ \\
\hline Private sector & $69,1 \%$ & $30,9 \%$ \\
\hline
\end{tabular}

Hoewel de mate van dynamiek weinig verschilt, verschillen wel de bronnen van dynamiek. Leidinggevenden in het publieke domein geven aan dat ze de meeste dynamiek ervaren als gevolg van veranderingen door politieke keuzes. Bij leidinggevenden in de private sector komt de ervaren dynamiek relatief evenredig uit de verschillende bronnen (zie tabel 3).

Tabel 3 Gebieden waarop dynamiek ervaren wordt per sector

\begin{tabular}{|l|l|l|l|l|l|}
\hline & Burgers/klanten & Wetgeving & Technologie & Politiek & Economie \\
\hline $\begin{array}{l}\text { Publieke } \\
\text { sector }\end{array}$ & $9,1 \%$ & $10,3 \%$ & $13,4 \%$ & $20,0 \%$ & $8,5 \%$ \\
\hline
\end{tabular}


Past de mate van wendbaarheid nu bij de dynamiek die organisaties ervaren? Een hoge dynamiek zou immers moeten worden beantwoord met een hoge mate van wendbaarheid. Als de dynamiek laag is, is wendbaarheid minder noodzakelijk. Uit de resultaten (figuur 2) blijkt dat het grootste deel van de organisaties in het publieke domein die een hoge dynamiek ervaren, dit niet beantwoordt met wendbaarheid: 29\% ervaart namelijk een hoge dynamiek en weinig wendbaarheid. Slechts $6 \%$ ervaart een hoge dynamiek en scoort tevens hoog op de wendbaarheid. Andersom is er ook een groep die weinig dynamiek ervaart, maar wél een hoge wendbaarheid heeft (14\%). Voor hen is het hebben van een wendbare organisatie minder noodzakelijk, maar blijkbaar zijn zij het wel. Dit hoeft op zichzelf niet schadelijk te zijn, maar men kan zich ook afvragen of het efficiënt is: mogelijk kosten de maatregelen om wendbaar te zijn meer dan dat zij de organisatie opleveren. Tot slot ervaart ongeveer de helft een lage dynamiek en lage wendbaarheid. Voor hen geldt een goede match en lijkt het dus, bezien vanuit de dynamiek die zij ervaren, minder urgent om de wendbaarheid te verhogen.

\section{Dynamiek versus wendbaarheid in de publieke sector (tussen haakjes private sector)}

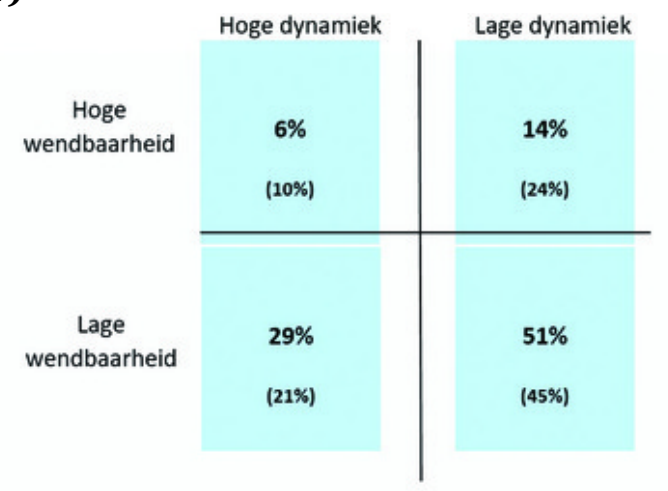

In de private sector zien we wat verschillen ten opzichte van de publieke sector. In de private sector is er vaker sprake van een wendbare organisatie als de dynamiek in de omgeving daarom vraagt (10\%). Voor $21 \%$ geldt dat de dynamiek niet wordt beantwoord met wendbaarheid. Daar staat wel tegenover dat als de dynamiek laag is, er in de private sector ook meer organisaties 'onnodig' wendbaar zijn dan in de publieke sector (24\%).

Tabel 4 Resultaten regressieanalyse wendbaarheid

\begin{tabular}{|c|c|}
\hline & Bèta \\
\hline Geslacht $(1=$ vrouw $)$ & 0,038 \\
\hline Leeftijd & 0,029 \\
\hline Span of control & $0,076^{*}$ \\
\hline $\begin{array}{l}\text { Organisatieomvang } \\
\text { k van onze websites geeft u }\end{array}$ & $\begin{array}{l}\text { 0,017 } \\
\text { cookies o }\end{array}$ \\
\hline
\end{tabular}




\begin{tabular}{|c|c|}
\hline Sector ( 1 = publiek) & $-0,079^{*}$ \\
\hline Dynamiek & $-0,040$ \\
\hline $\begin{array}{l}\text { De strategische kaders van ons organisatieonderdeel } \\
\text { bieden veel ruimte voor eigen initiatief }\end{array}$ & 0,014 \\
\hline $\begin{array}{l}\text { In ons organisatieonderdeel betrekken we medewerkers } \\
\text { actief bij het bepalen van de strategische kaders }\end{array}$ & $0,130^{* *}$ \\
\hline $\begin{array}{l}\text { In ons organisatieonderdeel sturen we vooral op te } \\
\text { behalen resultaten }\end{array}$ & 0,059 \\
\hline $\begin{array}{l}\text { Ons organisatieonderdeel heeft een flexibele schil in het } \\
\text { personeelsbestand dat meebeweegt met de eisen die de } \\
\text { omgeving van onze organisatie aan ons stelt }\end{array}$ & 0,011 \\
\hline $\begin{array}{l}\text { In ons organisatieonderdeel zijn we in staat om snel } \\
\text { nieuwe medewerkers aan te trekken }\end{array}$ & $0,117^{* *}$ \\
\hline $\begin{array}{l}\text { In ons organisatieonderdeel bouwen we actief aan een } \\
\text { goede relatie met universiteiten }\end{array}$ & 0,030 \\
\hline $\begin{array}{l}\text { In ons organisatieonderdeel zorgen we ervoor, dat } \\
\text { medewerkers waar we afscheid van nemen altijd als } \\
\text { ambassadeur van de organisatie vertrekken }\end{array}$ & 0,008 \\
\hline $\begin{array}{l}\text { We behandelen uitzendkrachten in ons HR-beleid } \\
\text { grotendeels hetzelfde als onze eigen medewerkers }\end{array}$ & 0,028 \\
\hline $\begin{array}{l}\text { In ons organisatieonderdeel detacheren we } \\
\text { medewerkers tijdelijk aan andere organisaties }\end{array}$ & $-0,012$ \\
\hline $\begin{array}{l}\text { In ons organisatieonderdeel kunnen we op initiatief van } \\
\text { de werkgever medewerkers per week meer of minder } \\
\text { uren laten werken (jaarurensystematiek) }\end{array}$ & $-0,093^{* *}$ \\
\hline $\begin{array}{l}\text { In ons organisatieonderdeel verwachten we van } \\
\text { medewerkers dat zij bereid zijn om over te werken } \\
\text { ongeacht een financiële vergoeding }\end{array}$ & 0,031 \\
\hline $\begin{array}{l}\text { In ons organisatieonderdeel stimuleren we horizontale } \\
\text { arbeidsmobiliteit }\end{array}$ & $-0,029$ \\
\hline $\begin{array}{l}\text { Het teruggaan van een medewerker uit een hogere } \\
\text { functie naar een lagere functie (demotie) is in ons } \\
\text { organisatieonderdeel een vanzelfsprekend onderdeel } \\
\text { van de interne mobiliteit }\end{array}$ & 0,055 \\
\hline $\begin{array}{l}\text { We stimuleren medewerkers in ons } \\
\text { organisatieonderdeel om 'stage' te lopen in een ander } \\
\text { team of afdeling }\end{array}$ & $-0,090^{*}$ \\
\hline $\begin{array}{l}\text { In ons organisatieonderdeel stimuleren we } \\
\text { medewerkers om nieuwe ideeën aan te brengen }\end{array}$ & 0,014 \\
\hline In ons organisatieonderdeel zijn we erop gericht om & \\
\hline
\end{tabular}


\begin{tabular}{|l|l|} 
In ons organisatieonderdeel maken we gebruik van de & $\mathbf{0 , 0 0 4}$
\end{tabular} kennis en ervaring van medewerkers met lange dienstverbanden

In ons organisatieonderdeel gebruiken we training als een manier om het informele netwerk te versterken 0,056

In ons organisatieonderdeel vieren we successen

De fysieke inrichting van ons pand is gericht op het creëren van ontmoetingen

In ons organisatieonderdeel experimenteren we actief met nieuwe ideeën

Evaluaties zijn in ons organisatieonderdeel onderdeel van onze werkprocessen

In ons organisatieonderdeel zorgen we dat het voor medewerkers duidelijk is bij wie ze bepaalde kennis op $\quad$ 0,075 kunnen halen

In ons organisatieonderdeel hebben we specifieke functies en rollen voor kennismanagement

In ons organisatieonderdeel bouwen we actief aan de relatie met universiteiten en scholen om snel te kunnen beschikken over de laatste inzichten in ons werkveld/vakgebied

In ons organisatieonderdeel maken we regelmatig gebruik van stagiairs en afstudeerders

In ons organisatieonderdeel nodigen we regelmatig sprekers van buiten uit

Medewerkers van ons organisatieonderdeel bezoeken regelmatig congressen en lezingen om nieuwe kennis op te doen

In ons organisatieonderdeel hebben we een duidelijk proces voor het in de gaten houden van externe ontwikkelingen

We laten mensen van buiten onze organisatie meedenken met de strategie van ons organisatieonderdeel

In ons organisatieonderdeel worden de kernactiviteiten grotendeels uitgevoerd in projectteams

In ons organisatieonderdeel worden kernactiviteiten grotendeels uitgevoerd door specialistische functies

Een projectteam heeft in ons organisatieonderdeel een duidelijk mandaat 


\begin{tabular}{|c|c|}
\hline $\begin{array}{l}\text { In ons organisatieonderdeel beslissen medewerkers zelf } \\
\text { in welk project ze deelnemen }\end{array}$ & $-0,020$ \\
\hline $\begin{array}{l}\text { We kiezen in ons organisatieonderdeel voor } \\
\text { vakspecialisatie van medewerkers, om een optimale } \\
\text { kwaliteit te kunnen leveren }\end{array}$ & 0,004 \\
\hline $\begin{array}{l}\text { We kiezen er in ons organisatieonderdeel voor om } \\
\text { generieke functies te hebben, om flexibele inzet van } \\
\text { medewerkers mogelijk te maken }\end{array}$ & $0,103^{* *}$ \\
\hline $\begin{array}{l}\text { Training voor medewerkers van ons } \\
\text { organisatieonderdeel is vooral gericht op het verder } \\
\text { verdiepen van hun specialisatie }\end{array}$ & 0,035 \\
\hline $\begin{array}{l}\text { Training voor medewerkers van ons } \\
\text { organisatieonderdeel is vooral gericht op het verbreden } \\
\text { van hun kennis en vaardigheden }\end{array}$ & $-0,016$ \\
\hline $\begin{array}{l}\text { Medewerkers in ons organisatieonderdeel weten elkaar } \\
\text { makkelijk te vinden om af te stemmen }\end{array}$ & 0,068 \\
\hline $\begin{array}{l}\text { In ons organisatieonderdeel stimuleren we } \\
\text { medewerkers om elkaar op te zoeken }\end{array}$ & 0,026 \\
\hline $\begin{array}{l}\text { In ons organisatieonderdeel hebben we veel regels en } \\
\text { procedures }\end{array}$ & 0,000 \\
\hline $\begin{array}{l}\text { De regels en procedures in ons organisatieonderdeel } \\
\text { zijn het gevolg van externe druk }\end{array}$ & 0,034 \\
\hline $\begin{array}{l}\text { Het volgen van regels en procedures is in ons } \\
\text { organisatieonderdeel belangrijk }\end{array}$ & 0,047 \\
\hline $\begin{array}{l}\text { Het ter discussie stellen van de regels en procedures } \\
\text { wordt in ons organisatieonderdeel gewaardeerd }\end{array}$ & $0,102^{* *}$ \\
\hline $\begin{array}{l}\text { Het werk van ons organisatieonderdeel is zo complex, } \\
\text { dat regels en procedures nodig zijn om het overzicht te } \\
\text { bewaren }\end{array}$ & $-0,021$ \\
\hline $\begin{array}{l}\text { In ons organisatieonderdeel informeren we } \\
\text { medewerkers over veranderingen in de omgeving van } \\
\text { onze organisatie }\end{array}$ & $0,076^{*}$ \\
\hline $\begin{array}{l}\text { Strategische besluitvorming vindt grotendeels in de top } \\
\text { van ons organisatieonderdeel plaats }\end{array}$ & $-0,020$ \\
\hline $\begin{array}{l}\text { We bieden medewerkers in ons organisatieonderdeel } \\
\text { actief de gelegenheid om mee te praten over de } \\
\text { strategie van ons onderdeel }\end{array}$ & $-0,095^{*}$ \\
\hline $\begin{array}{l}\text { Medewerkers in ons organisatieonderdeel hebben veel } \\
\text { autonomie om besluiten te nemen over hun eigen werk }\end{array}$ & 0,021 \\
\hline $\begin{array}{l}\text { De teams in ons organisatieonderdeel stellen hun eigen } \\
\text { teamdoelen vast, binnen de strategische kaders }\end{array}$ & 0,002 \\
\hline
\end{tabular}


leggen, zijn we in ons organisatieonderdeel beter in staat om te reageren op veranderingen in de omgeving van onze organisatie

Formele afstemming tussen teams of afdelingen van ons organisatieonderdeel is niet nodig, dat regelen de medewerkers informeel

Adjusted $R$ square

0,46

${ }^{*} \mathrm{p}<.05,{ }^{* *} \mathrm{p}<.01$

De resultaten van de regressieanalyse laten zien dat er een aantal managementpraktijken is die een organisatie kan toepassen om de wendbaarheid te vergroten, en een aantal managementpraktijken die organisaties vooral moeten laten om zo de wendbaarheid te vergroten. Zo zien we dat het actief betrekken van medewerkers bij de strategische kaders bijdraagt aan wendbaarheid, maar dat medewerkers actief laten meepraten over de strategie zelf een negatief effect heeft op de wendbaarheid van de organisatie.

Wendbare organisaties zijn verder in staat om snel nieuwe medewerkers aan te trekken, experimenteren actief met nieuwe ideeën, waarderen het wanneer regels en procedures ter discussie worden gesteld, hebben een duidelijk proces om externe ontwikkelingen in de gaten te houden, informeren medewerkers over deze ontwikkelingen, maken gebruik van generieke functies en leggen verantwoordelijkheid laag in de organisatie. Het gebruik van een jaarurensystematiek, het stimuleren van interne 'stages' en het uitvoeren van de kernactiviteiten in projectteams leiden juist tot minder wendbaarheid. Ten slotte zien we dat ook de span of control een positief effect heeft op de wendbaarheid van de organisatie.

\section{Discussie}

We bespreken hier de uitkomsten van de analyse. We beginnen met het positieve verband tussen de span of control en de wendbaarheid van de organisatie. Dit betekent dat hoe groter de span of control is, hoe hoger de mate van wendbaarheid is. Mogelijk heeft dit te maken met de beperkte 'bemoeienis' die een manager kan hebben bij een grote span of control. Wanneer een manager veel medewerkers moet aansturen, is het lastiger zich bezig te houden met alle details en met elk besluit. Dit betekent dat er meer verantwoordelijkheid en besluitvorming als van nature bij de medewerkers wordt gelegd. We zien in tabel 4 ook dat in wendbare organisaties verantwoordelijkheden laag in de organisatie worden gelegd, dat regels en procedures ter discussie worden gesteld, en dat er sprake is van generieke functies. Dit alles duidt op een hoge mate van autonomie in besluitvorming en een lage mate van formalisatie. Dit sluit aan bij het inzicht dat een hoge mate van autonomie in besluitvorming leidt tot meer ondernemerschap en bewegingsvrijheid om te reageren op dynamiek in de omgeving (Foss, Lyngsie, \& Zahra, 2015). Veel van de managementpraktijken die een positieve samenhang hebben met de wendbaarheid van de organisatie lijken erop gericht te zijn dat 
ontwikkelingen in de buitenwereld zijn manieren om een eenduidige interpretatie te bevorderen (Bowen \& Ostroff, 2004). Opvallend hierbij is dat medewerkers wel actief betrokken worden bij het bepalen van de strategische kaders, maar dat actief meepraten over de strategie zelf juist niet bijdraagt aan de wendbaarheid van de organisatie. Mogelijk bestaat er bij het bepalen van de strategie het risico van 'Poolse landdagen', terwijl de strategische kaders een concreet voortvloeisel zijn van de strategie van de organisatie. Hierover meepraten is dus enigszins gekaderd én heeft een meer direct en concreet effect op het dagelijks werk van de medewerkers. Daarnaast zou een mogelijke verklaring kunnen zijn dat de strategische kaders van invloed zijn op het vermogen om de inzet van mensen wendbaar te organiseren. De strategie zelf gaat daarentegen niet over het organiseren van mensen, maar meer over de te bereiken doelen dóór het organiseren van mensen.

Het makkelijk kunnen aantrekken van nieuwe medewerkers heeft een positief effect op de wendbaarheid van de organisatie. Het aantrekken van nieuwe medewerkers leidt namelijk niet alleen tot numerieke flexibiliteit (de beschikbaarheid over meer medewerkers), maar ook tot kwalitatieve flexibiliteit (de beschikbaarheid van medewerkers met andere competenties, vaardigheden en ideeën). Hierin zit een tegenstelling met het stimuleren van uitsluitend de numerieke flexibiliteit op basis van de jaarurensystematiek. Deze heeft namelijk een negatief verband met de wendbaarheid van de organisatie. De jaarurensystematiek biedt de werkgever de mogelijkheid om gedurende het jaar het aantal werkzame uren - van uitsluitend de huidige medewerkers - per week te laten fluctueren. Het effect op alleen de numerieke flexibiliteit verklaart echter nog niet noodzakelijkerwijs het negatieve verband tussen de toepassing van de jaarurensystematiek en de wendbaarheid van de organisatie. Een mogelijke verklaring is dat deze systematiek een procedureel instrument is om de ureninzet te laten fluctueren. Mogelijk hebben medewerkers in een wendbare organisatie juist geen behoefte aan een procedureel instrument en bepalen ze liever zelf - op basis van de dynamiek in de omgeving - op welke momenten ze meer of minder werken.

Opvallend is het negatieve verband met interne stages. De verwachting was dat men stages inzet om de blik van medewerkers breder te maken. Blijkbaar zijn interne stages hiervoor niet het meest logische instrument. Dit verklaart echter nog niet het significante negatieve verband met wendbaar organiseren. Wellicht moet de verklaring worden gezocht in het feit dat deze interne stages ook gebruikt worden als onderdeel van mobiliteitsbevorderende maatregelen in het kader van reorganisaties (bijvoorbeeld als onderdeel van 'Van Werk Naar Werk'-trajecten). Reorganisaties die wendbare organisaties juist weten te voorkomen. Tot slot zien we een negatief effect van het gebruik van projectteams voor de uitvoering van kernactiviteiten op de wendbaarheid van de organisatie. Over het algemeen wordt gesteld dat projectteams leiden tot een meer flexibele inzet van de beschikbare capaciteit, want een projectteam kan uit steeds wisselende samenstellingen bestaan en heeft een tijdelijk karakter. Wellicht heeft dit te maken met de toevoeging van 'kernactiviteiten'. Dit zijn de activiteiten die in ieder geval moeten worden 
In dit onderzoek zijn keuzes gemaakt waarover uiteraard discussie mogelijk is. We hebben leidinggevenden in het onderzoek gevraagd de wendbaarheid van hun organisatieonderdeel te beoordelen, in plaats van de hele organisatie. Dit roept echter de vraag op in hoeverre een organisatieonderdeel wendbaar kan zijn wanneer het opereert in een organisatie die als geheel niet wendbaar is, of die niet openstaat voor managementpraktijken gericht op wendbaarheid. Dit vraagt om aanvullend multilevel onderzoek. Daarnaast hebben we er in dit onderzoek voor gekozen om de dynamiek te meten door leidinggevenden vragen te stellen over de frequentie en onvoorspelbaarheid van veranderingen. Daarmee hebben we de perceptie van dynamiek in beeld gebracht en niet de feitelijke dynamiek. Verder heeft circa een kwart van de steekproef deelgenomen aan het onderzoek. Deze op het oog lage respons is niet ongebruikelijk bij deze vorm van panelonderzoek. Dit neemt echter niet weg dat hierdoor sprake kan zijn van een nonresponsbias. Tegelijkertijd is een hoog responspercentage geen garantie voor een accuratere meting (Visser, Krosnick, Marquette, \& Curtin, 1996). Ten aanzien van het onderzoeksonderwerp is het niet aannemelijk dat mensen om inhoudelijke redenen (bijvoorbeeld uit weerstand) besloten hebben niet deel te nemen aan het onderzoek, waardoor we ervan uitgaan dat er geen vertekend beeld ontstaan is door de mensen die wel deelgenomen hebben. Tot slot hebben we in dit onderzoek een vergelijking gemaakt tussen de publieke en de private sector. Hierbij zagen we dat - hoewel de bronnen van dynamiek verschillen - de mate van ervaren dynamiek zelf niet significant verschilt. Daarmee besteden wij nog geen aandacht aan de diversiteit binnen deze sectoren. Het is echter voor te stellen dat ook hierbij geldt dat de bronnen van dynamiek verschillen, zonder dat de mate van dynamiek zelf significant verschilt. Vervolgonderzoek dient uit te wijzen in hoeverre daar daadwerkelijk verschillen waar te nemen zijn.

\section{Conclusie}

Met dit onderzoek hebben we op verschillende manieren een bijdrage willen leveren aan de kennis over wendbare organisaties. Allereerst hebben we het concept wendbaarheid ontwikkeld, gemeten en gevalideerd. Daarnaast hebben we empirisch het afzonderlijke effect van verschillende managementpraktijken op het wendbaar vermogen van organisaties geïdentificeerd.

Dit onderzoek laat zien dat het lang niet voor alle organisatieonderdelen bij de overheid noodzakelijk is om een wendbare organisatie te zijn, bezien vanuit het perspectief van de ervaren dynamiek. Tegelijkertijd is er een substantiële groep die gezien de dynamiek die zij tegenkomt, wendbaarder zou mogen zijn. Het onderzoek biedt een aantal aanknopingspunten om dat te bereiken.

\section{Literatuur}

Bowen, D.E., \& Ostroff, C. (2004). Understanding HRM-firm

performance linkages: The role of the 'strength' of the HRM system. 
Christopher, M. (2000). The agile supply chain: Competing in volatile markets. Industrial Marketing Management, 29(1), 37-44.

Dess, G.G., \& Beard, D.W. (1984). Dimensions of organizational task environments. Administrative Science Quarterly, 29(1), 52-73.

Dyer, L., \& Ericksen, J. (2006). Dynamic organizations: Achieving marketplace agility through workforce scalability (CAHRS Working Paper \# 06-12). Ithaca, NY: Cornell University, School of Industrial and Labor Relations, Center for Advanced Human Resource Studies. Retrieved from http://digitalcommons.ilr.cornell.edu/cahrswp/454

Dyer, L., \& Shafer, R. (1999). From human resource strategy to organizational effectiveness: Lessons from research on organizational agility. In P. Wright, L. Dyer, J. Boudreau \& G. Milkovich (Eds.), Strategic human resource management in the 21st century: Research in personnel and human resource management. Supplement 4 (p. 145-174). Stamford, CT: JAI Press.

Dyer, L., \& Shafer, R. (2003). Dynamic organizations: Achieving marketplace and organizational agility with people. (CAHRS Working Paper \# 03-04). Ithaca, NY: Cornell University, School of Industrial and Labor Relations, Center for Advanced Human Resource Studies. Retrieved from http://digitalcommons.ilr.cornell.edu/cahrswp/27/.

Foss, N.J., Lyngsie, J., \& Zahra, S.A. (2015). Organizational design correlates of entrepreneurship: The roles of decentralization and formalization for opportunity discovery and realization. Strategic Organization, 13(1), 32-60.

Goldman, S.L., Nagel, R.N., \& Preiss, K. (1995). Agile competitors and virtual organizations: Strategies for enriching the customer. New York: Van Nostrand Reinhold.

Helfat, C., Finkelstein, S., Mitchell, W., Peteraf, M., Singh, H., Teece, D., \& Winter, S. (2007). Dynamic capabilities: Understanding strategic change in organizations. Malden, MA: Blackwell Publishing.

Huang, C.C. (1999). An agile approach to logical network analysis in decision support systems. Decision Support Systems, 25(1), 53-70.

Miles, R.E., Snow, C.C., \& Pfeffer, J. (1974). Organization-environment: Concepts and issues. Industrial Relations: A Journal of Economy and Society, 13(3), 244-264.

Nijssen, M., \& Paauwe, J. (2012a). HRM in turbulent times: How to achieve organizational agility? The International Journal of Human Resource Management, 23(16), 3315-3335.

Nijssen, M., \& Paauwe, J. (2012b). Overleven in een dynamische 
Nishii, L.H., \& Wright, P.M. (2008). Variability within organizations: Implications for strategic human management (CAHRS Working Paper \#07-02). Ithaca, NY: Cornell University, School of Industrial and Labor Relations, Center for Advanced Human Resource Studies. Retrieved from http://digitalcommons.ilr.cornell.edu/cahrswp/467

Oyen, M.P. van, Gel, E.G.S., \& Hopp, W.J. (2001). Performance opportunity for workforce agility in collaborative and non-collaborative work systems. IIE Transactions, 33, 761-777.

Steen, M.A. van der. (2018). Adaptief bestuur: organiseren voor een voorspelbaar verrassende toekomst. In Adaptief bestuur. Essays over adaptiviteit en openbaar bestuur. Ministerie van Binnenlandse Zaken en Koninkrijksrelaties.

Teece, D.J. (2007). Explicating dynamic capabilities: The nature and microfoundations of (sustainable) enterprise performance. Strategic Management Journal, 28(13), 1319-1350.

Ulrich, D., \& Lake, D.G. (1990). Organizational capability: Competing from the inside out. New York: John Wiley \& Sons.

Visser, P.S., Krosnick, J.A., Marquette, J., \& Curtin, M. (1996). Mail surveys for election forecasting? An evaluation of the Columbus Dispatch poll. Public Opinion Quarterly, 6o(2), 181-227.

Volberda, H. (1998). Building the flexible firm: How to remain competitive. Oxford: Oxford University Press.

Wall, T., Michie, J., Patterson, M., Wood, S., Sheehan, M., Clegg, C., \& West, M. (2004). On the validity of subjective measures of company performance. Personnel Psychology, 57(1), 95-111.

Drs. M. Nijssen is oprichter van en adviseur bij De Organisatie Ontwerpers en was ten tijde van het onderzoek als buitenpromovendus verbonden aan Tilburg University. Dr. B. Vermeeren is als universitair docent verbonden aan de Erasmus Universiteit Rotterdam en als senior adviseur aan ICTUInternetSpiegel. Drs. L. Vermeer is verbonden aan ICTU en is programmamanager van InternetSpiegel. Ir. J. Visser was ten tijde van het onderzoek als senior adviseur verbonden aan ICTUInternetSpiegel en is nu als docent verbonden aan de opleiding HRM van de Hogeschool van Amsterdam. 

meer informatie klik hier. 